\title{
Enterotoxin genes in coagulase-negative and coagulase-positive staphylococci isolated from bovine milk
}

\author{
Felipe de Freitas Guimarães, Diego Borin Nóbrega, Virginia Bodelão Richini-Pereira, Pâmela Merlo Marson, \\ José Carlos de Figueiredo Pantoja, and Helio Langoni ${ }^{1}$ \\ Department of Veterinary Hygiene and Public Health, School of Veterinary Medicine and Animal Science (FMVZ), São Paulo State University, \\ Botucatu, SP, Brazil 18618-970
}

\section{ABSTRACT}

The objective of this study was to isolate and identify the main staphylococcal species causing bovine mastitis in 10 Brazilian dairy herds and study their capability to produce enterotoxins. Herds were selected based on size and use of milking technology, and farms were visited once during the study. All mammary glands of all lactating cows were screened using the California Mastitis Test (CMT) and a strip cup. A single aseptic milk sample $(20 \mathrm{~mL})$ was collected from all CMT-positive quarters. Identification of Staphylococcus spp. was performed using conventional microbiology, and PCR was used to determine the presence of enterotoxinencoding genes (sea, seb, sec, and sed). Of the 1,318 CMT-positive milk samples, Staphylococcus spp. were isolated from $263(19.9 \%)$. Of these isolates, $135(51 \%)$ were coagulase-positive staphylococci (CPS) and 128 $(49 \%)$ were coagulase-negative staphylococci (CNS). Eighteen different species of CNS were isolated, among which S. warneri, S. epidermidis and S. hyicus were the most frequent. The distribution of Staphylococcus species was different among herds: S. epidermidis was found in 8 herds, $S$. warneri was found in 7 herds, and S. hyicus in 6 herds. Some of the CNS species (S. saprophyticus ssp. saprophyticus, S. auricularis, S. capitis, and $S$. chromogenes) were isolated in only one of the farms. Genes related to production of enterotoxins were found in $66 \%(\mathrm{n}=85)$ of all CNS and in $35 \%$ of the CPS isolates. For both CNS and CPS isolates, the most frequently identified enterotoxin genes were sea, seb, and sec; the prevalence of sea differed between CPS $(9.5 \%)$ and CNS (35.1\%) isolates. Staphylococcus warneri isolates showed a greater percentage of sea than seb, sec, or sed, whereas S. hyicus isolates showed a greater percentage of sea than sec. Over $60 \%$ of CNS belonged to 3 major species, which carried 62.2 to $81.3 \%$ of the enterotoxin genes. The high prevalence

Received June 22, 2012.

Accepted January 5, 2013.

${ }^{1}$ Corresponding author: hlangoni@fmvz.unesp.br highlights the potential for food poisoning caused by these species. For possible high-risk situations for food poisoning, such as milk produced with total bacterial counts greater than regulatory levels and stored under inappropriate temperatures, monitoring contamination with CNS could be important to protect human health. Because the prevalence of CNS intramammary infections in dairy herds is usually high, and these species can be found in great numbers in bulk milk, identification of risk factors for production of staphylococcal enterotoxins should be considered in future studies.

Key words: coagulase-negative staphylococci, bovine mastitis, polymerase chain reaction, enterotoxin gene

\section{INTRODUCTION}

Foodborne diseases are of major concern worldwide. Recent outbreaks highlight the need for reducing contamination with bacterial pathogens in foods of animal origin. Zoonotic bacteria can cause clinical disease, morbidity and mortality in animals and are a major source of economic loss to the livestock industry worldwide. Moreover, these pathogens can be carried asymptomatically and transmitted through the food chain to humans (Gaggia et al., 2010). More than 250 different foodborne diseases have been described, being bacteria the causative agents of two-thirds of foodborne disease outbreaks (Le Loir et al., 2003).

Among foodborne diseases, staphylococcal gastroenteritis results from consumption of food in which enterotoxigenic staphylococci have grown and produced toxins. Normally, they exert their effects on the gastrointestinal tract and therefore are called enterotoxins (Bergdoll, 1983). Symptoms are of rapid onset and include nausea and violent vomiting, with or without diarrhea (Bhatia and Zahoor, 2007). The illness is usually self-limiting and only occasionally severe enough to result in hospitalization.

Staphylococcus aureus is one of the leading causes of food poisoning in humans (Le Loir et al., 2003); S. aureus enterotoxins are highly stable and resistant to heat and most proteolytic enzymes such as pepsin or trypsin 
(Bhatia and Zahoor, 2007). Genes encoding the staphylococcal enterotoxins have different genetic structures, most of which are mobile genetic elements. These genes can be located in chromosomes, plasmids, and phages. Staphylococcal enterotoxin SEA is the most common cause of staphylococcal food poisoning worldwide, but the involvement of other staphylococcal enterotoxins has been also demonstrated (Argudín et al., 2010).

Among a wide range of staphylococcal species (Bannerman et al., 2003), the CNS have been considered to be largely saprophytic and rarely pathogenic (Kloos and Schleifer, 1975). Over the last decades, however, the CNS have been recognized as etiological agents of a series of infectious processes, representing one of the most frequently isolated microorganisms from human blood cultures and nosocomial infections (Huebner and Goldmann, 1999). Some studies have suggested an association between species of CNS and infections arising in hospitals (Vuong and Otto, 2002), with S. epidermidis being identified in 74 to $92 \%$ of patients with bacteremia (Martin et al., 1989). Several studies have reported a series of infections caused by other CNS species (Herwaldt et al., 1996), such as S. hemolyticus, which was the second most frequently detected species (Bannerman et al., 2003). Control of CNS infections may be complicated due to the presence of antibiotic resistance. Even et al. (2010) reported that $71 \%$ of the strains possessed at least one gene encoding antibiotic resistance.

In cattle, CNS have been recognized as emergent mastitis pathogens (Macovec and Ruegg, 2003; Nevala et al., 2004; Piepers et al., 2007; Costa et al., 2008). Several studies reported that CNS were the leading cause of subclinical mastitis and also associated with clinical mastitis. Subclinical cases have been associated with reduced milk production (Gröhn et al., 2004; De Vliegher et al., 2005; Taponen et al., 2006). In general, mastitis caused by CNS results in mild inflammation of the mammary gland. Quarters infected with CNS have lower SCC than quarters from which major pathogens are isolated (Pantoja et al., 2009). The presence of enterotoxin genes in CNS isolated from bovine mastitis has been described and enterotoxin production verified for some species (Bautista et al., 1988; Becker et al., 2001).

Because of the increase in the proportion of IMI caused by CNS in herds that have successfully controlled contagious mastitis, identification of species capable of producing enterotoxins would be important to determine and decrease the risk of human exposure to such hazards. Therefore, the purpose of this study was to study the distribution of staphylococcal species causing bovine mastitis in Brazilian dairy herds and their potential to produce enterotoxins.

\section{MATERIALS AND METHODS}

\section{Herd Selection and Sampling Strategy}

A convenience sample of 10 dairy herds in São Paulo state, Brazil, was used for the study. Herds were included in the study based on size (at least 80 lactating cows), and use of milking technology (machine-milked cows). Farms were visited once during the study. For each farm, all mammary glands of all lactating cows were screened using the California Mastitis Test (CMT) and a strip cup (Schalm and Noorlander, 1957). A single aseptic milk sample $(20 \mathrm{~mL})$ was collected from all CMT-positive quarters (even when visible abnormalities in milk were present) after udder preparation was performed by farm personnel.

\section{Laboratory Methods}

Isolates obtained from milk samples were plated (10 $\mu \mathrm{L}$ ) onto blood agar and incubated for up to $72 \mathrm{~h}$ at $37^{\circ} \mathrm{C}$. Samples were defined as contaminated if there were $>2$ bacterial species on a plate. Initial identification of Staphylococcus spp. was based on Gram staining and the catalase reaction. Isolates were then inoculated into brain heart infusion broth, as described by Kloos and Schleifer (1975). After incubation in brain heart infusion broth for $24 \mathrm{~h}$, staphylococcal species were determined using a series of biochemical tests.

Staphylococcus spp. were differentiated from Micrococcus spp. based on oxidation and fermentation of glucose, resistance to bacitracin (0.04 U), and susceptibility to furazolidone $(100 \mu \mathrm{g}$; Baker, 1984). Identification of Staphylococcus spp. was carried out according to the criteria suggested by Kloos and Schleifer (1975) and modified by Cunha et al. (2004). A series of biochemical tests was performed, including sugar fermentation (xylose, arabinose, sucrose, trehalose, maltose, mannitol, lactose, xylitol, ribose, fructose, and mannose), production of hemolysin, nitrate reduction, presence of urease and ornithine decarboxylase, and resistance to novobiocin. To confirm the identification of individual species, the following international reference CNS strains were used as controls: S. epidermidis (ATCC 12228), S. simulans (ATCC 27851), S. warneri (ATCC 10209), S. xylosus (ATCC 29979), S. saprophyticus (ATCC 15305) and S. aureus (ATCC 33591 and ATCC 25923). To confirm the identification of $S$. aureus, we used the primers Staur 4 and Staur 6, as described previously by Straub et al. (1999).

Polymerase chain reaction was used to determine enterotoxin genes (sea, seb, sec, and sed), and DNA extraction was carried out using the Illustra Blood GenomicPrep Mini Spin Kit (GE Healthcare, Chalfont 
St. Giles, UK). The PCR reactions were performed in a DNA thermal cycler (Mastercycler, Eppendorf, Hamburg, Germany) with primers described previously (Johnson et al., 1991). After electrophoresis in a $2 \%$ agarose gel and staining with SYBR Safe DNA stain (Invitrogen, Carlsbad, CA; $1 \mu \mathrm{L}$ in $10 \mathrm{~mL}$ of gel), the gel image was recorded and analyzed. Staphylococcus aureus strains ATCC 33591 and ATCC 25923 were used as positive controls.

Thermocycler parameters were as follows: for sea, initial denaturation was at $94^{\circ} \mathrm{C}$ for $4 \mathrm{~min}$, and then denaturation at $94^{\circ} \mathrm{C}$ for $2 \mathrm{~min}$, annealing at $51^{\circ} \mathrm{C}$ for 2 min, and extension at $72^{\circ} \mathrm{C}$ for $1 \mathrm{~min} 30 \mathrm{~s}$, denaturation at $94^{\circ} \mathrm{C}$ for $2 \mathrm{~min}$, annealing at $53^{\circ} \mathrm{C}$ for $2 \mathrm{~min}$, and extension at $72^{\circ} \mathrm{C}$ for $1 \mathrm{~min} 30 \mathrm{~s}$ for 35 cycles, and a final extension at $72^{\circ} \mathrm{C}$ for $7 \mathrm{~min}$. For seb, initial denaturation was at $94^{\circ} \mathrm{C}$ for $4 \mathrm{~min}$, and then denaturation at $94^{\circ} \mathrm{C}$ for $2 \mathrm{~min}$, annealing at $55.5^{\circ} \mathrm{C}$ for $2 \mathrm{~min}$, and extension at $72^{\circ} \mathrm{C}$ for $1 \mathrm{~min} 30 \mathrm{~s}$ for 38 cycles, and a final extension at $72^{\circ} \mathrm{C}$ for $7 \mathrm{~min}$. For sec, initial denaturation was at $94^{\circ} \mathrm{C}$ for $4 \mathrm{~min}$, and then denaturation at $94^{\circ} \mathrm{C}$ for $2 \mathrm{~min}$, annealing at $52.4^{\circ} \mathrm{C}$ for $2 \mathrm{~min}$, and extension at $72^{\circ} \mathrm{C}$ for $1 \mathrm{~min} 30 \mathrm{~s}$ for 38 cycles, and a final extension at $72^{\circ} \mathrm{C}$ for $7 \mathrm{~min}$. For sed, initial denaturation was at $94^{\circ} \mathrm{C}$ for $4 \mathrm{~min}$, and then denaturation at $94^{\circ} \mathrm{C}$ for 2 min, annealing at $55^{\circ} \mathrm{C}$ for 2 min and extension at $72^{\circ} \mathrm{C}$ for $1 \mathrm{~min} 30 \mathrm{~s}$, denaturation at $94^{\circ} \mathrm{C}$ for $2 \mathrm{~min}$, annealing at $53^{\circ} \mathrm{C}$ for $2 \mathrm{~min}$ and extension at $72^{\circ} \mathrm{C}$ for $1 \mathrm{~min}$ $30 \mathrm{~s}$, denaturation at $94^{\circ} \mathrm{C}$ for $2 \mathrm{~min}$, annealing at $51^{\circ} \mathrm{C}$ for $2 \mathrm{~min}$ and extension at $72^{\circ} \mathrm{C}$ for $1 \mathrm{~min} 30 \mathrm{~s}$ for 38 cycles, and a final extension at $72^{\circ} \mathrm{C}$ for $7 \mathrm{~min}$.

\section{Statistical Analysis}

Frequency distributions were produced to present the data. The Chi-squared or Fisher's Exact Test (PROC FREQ; SAS Institute, 2009) were used to compare the proportion of (1) coagulase-positive staphylococci (CPS) isolated; (2) genes related to production of enterotoxins between CNS and CPS; and (3) genes related to production of enterotoxins within CNS or CPS species. Statistical significance was defined at a confidence level of 0.05 .

\section{RESULTS}

Among 1,203 cows, CMT analysis of 4,592 mammary glands revealed that 1,318 samples were positive, from which milk samples were collected and used for microbiological examination. Of the 1,318 CMT-positive milk samples, Staphylococcus spp. were isolated from $263(19.9 \%)$. Of these isolates, $135(51 \%)$ were CPS and $128(49 \%)$ were CNS. Of the CPS isolated, most $(68 \%, \mathrm{n}=90)$ were $S$. aureus, $15 \%(\mathrm{n}=21)$ were $S$. intermedius, $13 \%(\mathrm{n}=19)$ were S. hyicus, and $4 \%(\mathrm{n}=$ $5)$ were $S$. schleiferi ssp. coagulans $(P<0.01)$.

Eighteen species of CNS were isolated, among which S. warneri, S. epidermidis, and S. hyicus were the most frequent (Table 1). The distribution of Staphylococcus spp. was different among herds (Tables 1 and 2). Among the CNS, S. epidermidis was found in 8 herds, $S$. warneri was found in 7 herds, and $S$. hyicus in 6 herds. Some of the CNS species (S. saprophyticus ssp. saprophyticus, S. auricularis, S. capitis, and S. chromogenes) were isolated in only 1 of the farms (Table 1 ).

Genes related to production of enterotoxins were found in $66 \%(\mathrm{n}=85)$ of all CNS and $35 \%$ of the CPS isolates $(P<0.01)$. For both CNS and CPS isolates, the most enterotoxin genes were sea, seb, and sec (Table $3)$. The prevalence of sea differed between CPS (9.5\%) and CNS $(35.1 \%)$ isolates $(P<0.01)$.

The staphylococcal enterotoxin genes detected by PCR in the S. warneri, S. epidermidis and S. hyicus isolated from bovine mastitis are presented in Table 3. Staphylococcus warneri isolates showed a greater percentage of sea than seb $(P<0.01)$, sec $(P<0.01)$, and sed $(P<0.01)$. Staphylococcus hyicus isolates showed a greater percentage of sea than sec $(P<0.01$; Table 3$)$.

Isolation and distribution of enterotoxin genes for the main CPS species ( $S$. aureus, $S$. intermedius, and $S$. hyicus) are presented in Table 2 . The enterotoxin genes were more frequently found in $S$. epidermidis, $S$. warneri, or $S$. hyicus compared with $S$. aureus $(P<0.05$ for each comparison, Table 3 ). In contrast, no difference in the frequency of isolation of these genes was found among CNS species (Table 3).

\section{DISCUSSION}

It has been consistently demonstrated that CNS species play an important role in mastitis etiology (Macovec and Ruegg, 2003; Nevala et al., 2004; Piepers et al., 2007; Costa et al., 2008). In total, 18 CNS species were isolated from bovine mastitis, among which $S$. hyicus, S. warneri, and S. epidermidis were the most prevalent. These 3 species were prevalent among pathogens causing IMI in previous studies. Costa et al. (2008) studied IMI caused by CNS in Brazilian herds located in the states of São Paulo and Pernambuco, and reported that S. warneri (45.5\%), S. hyicus (18.2\%), S. chromogenes (14.3\%), and S. epidermidis (5.2\%) were the most prevalent.

Milk from subclinically infected cows can be hazardous to human health not only because of the risk of pathogen transmission, but also because of contamination with enterotoxins. Surprisingly, enterotoxin genes were more prevalent among CNS than in S. aureus. We observed that approximately twice as many CNS 
Table 1. Distribution of CNS isolates and the presence of enterotoxin-encoding genes from bovine mastitis cases among 10 dairy herds (I to X)

\begin{tabular}{|c|c|c|c|c|c|c|c|c|c|c|c|c|c|c|c|c|c|c|c|c|c|c|}
\hline \multirow[b]{2}{*}{ CNS } & \multicolumn{2}{|c|}{ I } & \multicolumn{2}{|c|}{ II } & \multicolumn{2}{|c|}{ III } & \multicolumn{2}{|c|}{ IV } & \multicolumn{2}{|c|}{$\mathrm{V}$} & \multicolumn{2}{|c|}{ VI } & \multicolumn{2}{|c|}{ VII } & \multicolumn{2}{|c|}{ VIII } & \multicolumn{2}{|c|}{ IX } & \multicolumn{2}{|c|}{$\mathrm{X}$} & \multicolumn{2}{|c|}{ Total } \\
\hline & CNS & $\mathrm{EG}^{1}$ & CNS & EG & CNS & EG & CNS & EG & CNS & EG & CNS & EG & CNS & EG & CNS & EG & CNS & EG & $\mathrm{CNS}$ & EG & CNS & EG \\
\hline S. auricularis & 0 & 0 & 1 & 0 & 0 & 0 & 0 & 0 & 0 & 0 & 0 & 0 & 0 & 0 & 0 & 0 & 0 & 0 & 0 & 0 & 1 & 0 \\
\hline S. capitis & 0 & 0 & 1 & 1 & 0 & 0 & 0 & 0 & 0 & 0 & 0 & 0 & 0 & 0 & 0 & 0 & 0 & 0 & 0 & 0 & 1 & 1 \\
\hline S. chromogenes & 0 & 0 & 0 & 0 & 0 & 0 & 0 & 0 & 0 & 0 & 0 & 0 & 0 & 0 & 1 & 0 & 0 & 0 & 0 & 0 & 1 & 0 \\
\hline S. cohnii ssp. cohnii & 0 & 0 & 2 & 2 & 1 & 0 & 0 & 0 & 1 & 1 & 0 & 0 & 0 & 0 & 0 & 0 & 0 & 0 & 0 & 0 & 4 & 3 \\
\hline S. epidermidis & 4 & 1 & 5 & 5 & 4 & 4 & 1 & 0 & 2 & 2 & 0 & 0 & 1 & 0 & 1 & 0 & 0 & 0 & 1 & 0 & 19 & 12 \\
\hline S. hemolyticus & 1 & 1 & 2 & 2 & 0 & 0 & 0 & 0 & 0 & 0 & 2 & 1 & 1 & 0 & 0 & 0 & 0 & 0 & 0 & 0 & 6 & 4 \\
\hline S. hominis & 0 & 0 & 0 & 0 & 2 & 1 & 3 & 2 & 0 & 0 & 0 & 0 & 0 & 0 & 0 & 0 & 1 & 0 & 0 & 0 & 6 & 3 \\
\hline S. hyicus & 2 & 1 & 7 & 7 & 3 & 2 & 2 & 1 & 1 & 1 & 0 & 0 & 0 & 0 & 0 & 0 & 1 & 1 & 0 & 0 & 16 & 13 \\
\hline S. lugdunensis & 0 & 0 & 0 & 0 & 1 & 1 & 0 & 0 & 0 & 0 & 1 & 0 & 0 & 0 & 0 & 0 & 0 & 0 & 0 & 0 & 2 & 1 \\
\hline S. pasteuri & 0 & 0 & 0 & 0 & 1 & 0 & 1 & 1 & 0 & 0 & 2 & 1 & 0 & 0 & 0 & 0 & 1 & 1 & 0 & 0 & 5 & 3 \\
\hline S. saccharolyticus & 1 & 0 & 0 & 0 & 1 & 1 & 0 & 0 & 0 & 0 & 0 & 0 & 0 & 0 & 0 & 0 & 0 & 0 & 0 & 0 & 2 & 1 \\
\hline $\begin{array}{l}\text { S. saprophyticus } \\
\text { ssp. bovis }\end{array}$ & 0 & 0 & 0 & 0 & 0 & 0 & 0 & 0 & 0 & 0 & 1 & 0 & 0 & 0 & 0 & 0 & 0 & 0 & 0 & 0 & 1 & 0 \\
\hline $\begin{array}{l}\text { S. saprophyticus } \\
\text { ssp. saprophyticus }\end{array}$ & 3 & 2 & 0 & 0 & 0 & 0 & 0 & 0 & 0 & 0 & 0 & 0 & 0 & 0 & 0 & 0 & 0 & 0 & 0 & 0 & 3 & 2 \\
\hline $\begin{array}{l}\text { S. schleiferi ssp. } \\
\text { schleiferi }\end{array}$ & 1 & 0 & 1 & 1 & 1 & 1 & 3 & 1 & 0 & 0 & 0 & 0 & 0 & 0 & 0 & 0 & 0 & 0 & 0 & 0 & 6 & 3 \\
\hline S. sciuri ssp. sciuri & 0 & 0 & 1 & 1 & 1 & 1 & 0 & 0 & 0 & 0 & 1 & 0 & 0 & 0 & 0 & 0 & 0 & 0 & 0 & 0 & 3 & 2 \\
\hline S. simulans & 0 & 0 & 1 & 1 & 1 & 1 & 1 & 0 & 0 & 0 & 0 & 0 & 1 & 1 & 0 & 0 & 0 & 0 & 0 & 0 & 4 & 3 \\
\hline S. warneri & 2 & 1 & 12 & 8 & 14 & 14 & 6 & 3 & 4 & 4 & 1 & 1 & 1 & 0 & 0 & 0 & 0 & 0 & 0 & 0 & 40 & 31 \\
\hline S. xylosus & 0 & 0 & 2 & 2 & 2 & 1 & 2 & 0 & 0 & 0 & 1 & 0 & 1 & 0 & 0 & 0 & 0 & 0 & 0 & 0 & 8 & 3 \\
\hline Total & 14 & 6 & 35 & 31 & 32 & 27 & 19 & 9 & 8 & 8 & 9 & 3 & 5 & 1 & 2 & 0 & 3 & 2 & 1 & 0 & 128 & 85 \\
\hline
\end{tabular}

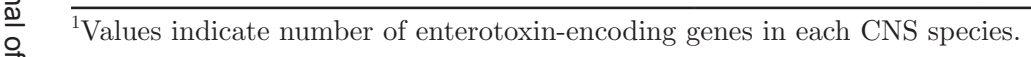




\begin{tabular}{|c|c|c|c|c|c|c|c|c|c|c|c|c|c|c|c|c|c|c|c|c|c|c|}
\hline \multirow{2}{*}{$\begin{array}{l}\text { Coagulase-positive } \\
\text { staphylococci }\end{array}$} & \multicolumn{2}{|c|}{ I } & \multicolumn{2}{|c|}{ II } & \multicolumn{2}{|c|}{ III } & \multicolumn{2}{|c|}{ IV } & \multicolumn{2}{|c|}{ V } & \multicolumn{2}{|c|}{ VI } & \multicolumn{2}{|c|}{ VII } & \multicolumn{2}{|c|}{ VIII } & \multicolumn{2}{|c|}{ IX } & \multicolumn{2}{|c|}{$\mathrm{X}$} & \multicolumn{2}{|c|}{ Total } \\
\hline & CPS & $\mathrm{EG}^{1}$ & CPS & EG & CPS & EG & CPS & EG & CPS & EG & CPS & EG & CPS & EG & CPS & EG & CPS & EG & CPS & EG & CPS & EG \\
\hline S. hyicus & 4 & 1 & 3 & 1 & 4 & 0 & 3 & 3 & 2 & 2 & 1 & 0 & 0 & 0 & 0 & 0 & 2 & 2 & 0 & 0 & 19 & 9 \\
\hline S. intermedius & 9 & 0 & 2 & 0 & 4 & 3 & 2 & 0 & 3 & 3 & 0 & 0 & 0 & 0 & 0 & 0 & 1 & 0 & 0 & 0 & 21 & 6 \\
\hline S. schleiferi ssp. coagulans & 3 & 1 & 0 & 0 & 1 & 0 & 1 & 0 & 0 & 0 & 0 & 0 & 0 & 0 & 0 & 0 & 0 & 0 & 0 & 0 & 5 & 1 \\
\hline S. aureus & 2 & 2 & 0 & 0 & 4 & 4 & 2 & 0 & 1 & 1 & 1 & 0 & 1 & 0 & 11 & 3 & 8 & 7 & 60 & 8 & 90 & 25 \\
\hline Total & 18 & 4 & 5 & 1 & 10 & 7 & 8 & 3 & 6 & 6 & 2 & 0 & 1 & 0 & 11 & 3 & 11 & 9 & 60 & 8 & 135 & 41 \\
\hline
\end{tabular}

${ }^{1}$ Values indicate number of enterotoxin-encoding genes in each CPS species.

Table 3. Classical staphylococcal enterotoxin-encoding genes detected by PCR in the main species of coagulase-positive and coagulase-negative staphylococci isolated from bovine mastitis of 10 dairy herds

\begin{tabular}{|c|c|c|c|c|c|c|c|c|c|c|c|c|c|c|c|c|}
\hline \multirow[b]{3}{*}{ Enterotoxin gene(s) } & \multicolumn{8}{|c|}{ Coagulase-positive staphylococci } & \multicolumn{8}{|c|}{ Coagulase-negative staphylococci } \\
\hline & \multicolumn{2}{|c|}{ S. aureus } & \multicolumn{2}{|c|}{ S. intermedius } & \multicolumn{2}{|c|}{ S. hyicus } & \multicolumn{2}{|c|}{ Total } & \multicolumn{2}{|c|}{ S. warneri } & \multicolumn{2}{|c|}{ S. epidermidis } & \multicolumn{2}{|c|}{ S. hyicus } & \multicolumn{2}{|c|}{ Total } \\
\hline & No. & $\%$ & No. & $\%$ & No. & $\%$ & No. & $\%$ & No. & $\%$ & No. & $\%$ & No. & $\%$ & No. & $\%$ \\
\hline sea & 10 & 11.1 & 0 & 0 & 5 & 29.4 & 15 & $11.8^{\mathrm{a}}$ & 25 & 62.5 & 8 & 42.1 & 10 & 62.5 & 43 & $57.3^{\mathrm{b}}$ \\
\hline$s e b$ & 6 & 6.7 & 1 & 5.0 & 0 & 0 & 7 & 5.5 & 4 & 10.0 & 1 & 5.3 & 4 & 25.0 & 9 & 12.0 \\
\hline $\mathrm{sec}$ & 5 & 5.5 & 1 & 5.0 & 2 & 11.8 & 8 & 6.3 & 10 & 25.0 & 3 & 15.8 & 1 & 6.3 & 14 & 18.7 \\
\hline sed & 2 & 2.2 & 0 & 0 & 1 & 5.8 & 3 & 2.4 & 5 & 12.5 & 4 & 21.1 & 0 & 0 & 9 & 12.0 \\
\hline$s e a+s e b+s e c$ & 2 & 2.2 & 0 & 0 & 0 & 0 & 2 & 1.6 & 0 & 0 & 0 & 0 & 0 & 0 & 0 & 0 \\
\hline$s e c+s e d$ & 2 & 2.2 & 4 & 20.0 & 1 & 5.8 & 7 & 5.5 & 3 & 7.5 & 1 & 5.3 & 0 & 0 & 4 & 5.3 \\
\hline$s e a+s e c$ & 0 & 0 & 1 & 5.0 & 0 & 0 & 1 & 0.8 & 3 & 7.5 & 0 & 0 & 0 & 0 & 3 & 4.0 \\
\hline$s e a+s e c+s e d$ & 1 & 1.1 & 0 & 0 & 1 & 5.8 & 2 & 1.6 & 2 & 5.0 & 2 & 10.2 & 0 & 0 & 4 & 5.3 \\
\hline$s e b+s e c$ & 0 & 0 & 0 & 0 & 0 & 0 & 0 & 0 & 1 & 2.5 & 0 & 0 & 0 & 0 & 1 & 1.3 \\
\hline sea + sed & 0 & 0 & 0 & 0 & 0 & 0 & 0 & 0 & 0 & 0 & 0 & 0 & 0 & 0 & 0 & 0 \\
\hline$s e a+s e b$ & 1 & 1.1 & 0 & 0 & 1 & 5.8 & 2 & 1.6 & 2 & 5.0 & 0 & 0 & 2 & 12.5 & 4 & 5.3 \\
\hline Positive & 29 & 32.2 & 7 & 35.0 & 11 & 64.7 & 47 & $37.0^{\mathrm{a}}$ & 31 & 77.5 & 12 & 62.2 & 13 & 81.3 & 56 & $74.7^{\mathrm{b}}$ \\
\hline Negative & 61 & 67.8 & 13 & 65.0 & 6 & 35.3 & 80 & 63.0 & 9 & 22.5 & 7 & 36.8 & 3 & 18.7 & 19 & 25.3 \\
\hline Total & 90 & 100.0 & 20 & 100.0 & 17 & 100.0 & 127 & 100.0 & 40 & 100 & 19 & 100 & 16 & 100 & 75 & 100 \\
\hline
\end{tabular}

${ }^{\mathrm{a}, \mathrm{b}}$ Different superscripts within the same row indicate significant differences between proportions $(P<0.05)$. 
isolates showed the classical enterotoxin genes (sea, seb, sec, and sed) as S. aureus isolates (64.4 and $32.2 \%$, respectively). Although safety hazards associated with CNS have been mostly associated with the presence of antibiotic resistance (Even et al., 2010), it is important to note that some CNS species found in this study (carrying enterotoxin genes) have been reported as frequent causes of human disease and could be transmitted through unpasteurized milk. In fact, several CNS food poisoning outbreaks have been described (Omori and Kato, 1959; Breckinridge and Bergdoll, 1971; Carmo et al., 2002; Veras et al., 2003).

Previous studies have reported the prevalence of enterotoxin genes among CNS isolates. In France, among 61 strains isolated from raw milk cheeses, $15.9 \%$ were enterotoxigenic (Rosec et al., 1997). In another study, Park et al. (2011) researched 19 classical and newly described enterotoxin genes from 263 CNS isolated from mastitic cows and showed $31.2 \%$ carried enterotoxin genes. Production of staphylococcal enterotoxins has been verified in some species of CNS such as S. cohnii, S. epidermidis, S. hemolyticus, and S. xylosus (Bautista et al., 1988), S. chromogenes, S. warneri, S. sciuri, S. saprophyticus, and S. lentus (Becker et al., 2001). In a previous Brazilian study, Brabes et al. (1999) reported enterotoxin production by $S$. sciuri and $S$. chromogenes. Although production of staphylococcal enterotoxin could not be confirmed, the high prevalence of CNS carrying enterotoxin genes in this study suggests that more attention should be given to examination of dairy products and the conditions (such as milk temperature) that trigger production of staphylococcal enterotoxins.

Among CNS species, S. epidermidis is one of the most pathogenic for human health (Even et al., 2010). In the latter study, $76 \%$ of the CNS carrying genes encoding staphylococcal toxins were S. epidermidis. Results of the present study corroborate the results of Even et al. (2010): most $(63.2 \%)$ S. epidermidis strains isolated from mastitic milk showed enterotoxin-encoding genes, predominantly sea, seb, and sed. Moreover, other CNS species carried enterotoxin genes in high percentages, such as $S$. warneri $(77.5 \%)$ and S. hyicus $(81.3 \%)$. In the present study, we verified the predominance of sea in both CNS and CPS. The most frequent enterotoxin genes found in CNS were sea $(35.1 \%)$, seb $(7.1 \%)$, and sec $(6.5 \%)$. The sea gene has been linked to most cases of staphylococcal food poisoning worldwide, but involvement of other classical enterotoxins has been also demonstrated (Argudín et al., 2010). These findings suggest that studies aiming to identify risk factors for production of enterotoxin by multiple CNS species are important to protect public health.

\section{CONCLUSIONS}

The high prevalence of CNS carrying staphylococcal enterotoxin genes found in this study highlights the potential for food poisoning caused by these species. In possible high-risk situations, such as milk produced with total bacterial counts greater than regulatory levels and stored under inappropriate temperatures, monitoring contamination with CNS could be important to protect human health. Because the prevalence of CNS IMI in dairy herds is usually high, and these species can be found in great numbers in bulk milk, identification of risk factors for production of staphylococcal enterotoxins should be considered in future studies.

\section{ACKNOWLEDGMENTS}

This study was funded by FAPESP (The São Paulo State Official Foundation to Support Research; grant number 2008/11614-1). F. F. Guimarães (grant numbers $2008 / 08780-7$ and $2011 / 21142-2$ ) is grateful for the grant and financial support received for this research. We thank Maria de Lourdes R. de Souza da Cunha [Department of Microbiology and Immunology, Biosciences Institute Botucatu (UNESP), Botucatu, Brazil] for providing the reference samples used in this study.

\section{REFERENCES}

Argudín, M. Á., M. C. Mendoza, and M. R. Rodicio. 2010. Food poisoning and Staphylococcus aureus enterotoxins. Toxins 2:17511773 .

Baker, J. S. 1984. Comparison of various methods for differentiation of staphylococci and micrococci. J. Clin. Microbiol. 19:875-879.

Bannerman, T. L., P. R. Murray, E. J. Baron, J. H. Jorgensen, M. A. Pfaller, and R. H. Yolken. 2003. Staphylococcus, Micrococcus and other catalase-positive cocci that grow aerobically. Pages 384-404 in Manual of Clinical Microbiology. 8th ed. American Society for Microbiology, Washington, DC.

Bautista, L., P. Gaya, M. Medina, and M. Nuñez. 1988. A quantitative study of enterotoxin production by sheep milk staphylococci. Appl. Environ. Microbiol. 59:566-569.

Becker, K., B. Keller, C. Von Eiff, M. Brück, G. Lubritz, J. Etienne, and G. Peters. 2001. Enterotoxigenic potential of Staphylococcus intermedius. Appl. Environ. Microbiol. 67:5551-5557.

Bergdoll, M. S. 1983. Enterotoxins. Pages 559-598 in Staphylococci and Staphylococcal Infections. C. S. F. Easman and C. Adlam, ed. Academic Press, London, UK.

Bhatia, A., and S. Zahoor. 2007. Staphylococcus aureus enterotoxins: A review. J. Clin. Diag. Res. 3:188-197.

Brabes, K. C. S., E. P. Carvalho, F. L. Dionisio, M. L. Pereira, F. Garino Jr., and E. O. Costa. 1999. Participação de espécies coagulase positivas e negativas produtoras de enterotoxinas do gênero Staphylococcus na etiologia de casos de mastite bovina em propriedades de produção leiteira dos Estados de São Paulo e Minas Gerais. Rev. Napgama 2:4-11.

Breckinridge, J. C., and M. S. Bergdoll. 1971. Outbreak of food-borne gastroenteritis due to a coagulase negative enterotoxin producing Staphylococcus. N. Engl. J. Med. 284:541-543. 
Carmo, L. S., R. S. Dias, V. R. Linardi, M. J. Sena, D. A. Santos, M. E. Faria, E. C. Pena, M. Jett, and L. G. Heneine. 2002. Food poisoning due to enterotoxigenic strains of Staphylococcus present in Minas cheese and raw milk in Brasil. Food Microbiol. 19:9-14.

Costa, E. O., F. F. Guimarães, P. Y. Faccioli, F. Santos, H. Langoni, J. Arcaro, A. Peres, and M. L. Cunha. 2008. Identification of the coagulase-negative staphylococci isolates from bovine mastitis and evaluation of the inflammatory. Page 73 in Proc. XXV Jubilee World Buiatrics Congress. Alapította, Budapest, Hungary.

Cunha, M. L. R. S., Y. K. Sinzato, and L. V. A. Silveira. 2004. Comparison of methods for the identification of coagulase-negative staphylococci. Mem. Inst. Oswaldo Cruz 99:855-860.

De Vliegher, S., H. W. Barkema, H. Stryhn, G. Opsomer, and A. De Kruif. 2005. Impact of early lactation somatic cell count in heifers on milk yield over the first lactation. J. Dairy Sci. 88:938-947.

Even, S., S. Leroy, C. Chalier, N. B. Zakour, J. Chacornac, I. Lebert, E. Jamet, M. Desmonts, E. Coton, S. Pochets, P. Donnio, M. Gautier, R. Talon, and Y. Le Loir. 2010. Low occurrence of safety hazards in coagulase negative staphylococci isolated from fermented foodstuffs. Int. J. Food Microbiol. 139:87-95.

Gaggia, F., P. Mattarelli, and B. Biavati. 2010. Probiotics and prebiotics in animal feeding for safe food production. Int. J. Food Microbiol. 141:S15-S28.

Gröhn, Y. T., D. J. Wilson, R. N. González, J. A. Hertil, H. Schulte, G. Bennett, and Y. H. Schukken. 2004. Effect of pathogen-specific clinical mastitis on milk yield in dairy cows. J. Dairy Sci. 87:3358-3374.

Herwaldt, L. A., M. Geiss, C. Kao, and M. Pfaller. 1996. The positive value of isolating coagulase-negative staphylococci from blood cultures. Clin. Infect. Dis. 22:14-20.

Huebner, J., and D. A. Goldmann. 1999. Coagulase-negative staphylococci: Role as pathogens. Annu. Rev. Med. 50:223-236.

Johnson, W. M., S. D. Tyler, E. P. Ewan, F. E. Ashton, D. R. Pollard, and K. R. Rozee. 1991. Detection of genes for enterotoxins, exfoliative toxins, and toxic shock syndrome toxin 1 in Staphylococcus aureus by the polymerase chain reaction. J. Clin. Microbiol. 29:426-430.

Kloos, W. E., and K. H. Schleifer. 1975. Simplified scheme for routine identification of human Staphylococcus species. J. Clin. Microbiol. $1: 82-88$.

Le Loir, Y., F. Baron, and M. Gautier. 2003. Staphylococcus aureus and food poisoning. Genet. Mol. Res. 2:63-76.

Macovec, J. A., and P. L. Ruegg. 2003. Results of milk samples submitted for microbiological examination in Wisconsin from 1994 to 2001. J. Dairy Sci. 86:3466-3472.
Martin, M. A., M. A. Pfaller, and R. P. Wenzel. 1989. Coagulasenegative staphylococcal bacteremia. Ann. Intern. Med. 110:9-16.

Nevala, M., S. Taponen, and S. Pyörälä. 2004. Bacterial etiology of bovine clinical mastitis-Data from Saari ambulatory clinic in 2002-2003. Suomen Eläinlääkärilehti 110:363-369.

Omori, G., and Y. A. Kato. 1959. Staphylococcal food-poisoning caused by a coagulase-negative strain. Biken J. 2:92-96.

Pantoja, J. C. F., C. Hulland, and P. L. Ruegg. 2009. Dynamics of somatic cell counts and intramammary infections across the dry period. Prev. Vet. Med. 90:43-54.

Park, J. Y., L. K. Fox, K. S. Seo, M. A. McGuire, Y. H. Park, F. R. Rurangirwa, W. M. Sischo, and G. A. Bohach. 2011. Detection of classical and newly described staphylococcal superantigen genes in coagulase-negative staphylococci isolated from bovine intramammary infections. Vet. Microbiol. 147:149-154.

Piepers, S., K. De Meulemeester, L. De Aart, G. Oopsomer, H. W. Barkema, and S. Vliegher. 2007. Prevalence and distribution of mastitis pathogens in subclinically infected dairy cows in Flanders, Belgium. J. Dairy Res. 74:478-483.

Rosec, J. P., J. P. Guiraud, C. Dalet, and N. Richard. 1997. Enterotoxin production by staphylococci isolated from foods in France. Int. J. Food Microbiol. 35:213-221.

SAS Institute. 2009. SAS/STAT 9.2 User's Guide. 2nd ed. SAS Institute Inc., Cary, NC.

Schalm, O. W., and D. O. Noorlander. 1957. Experimental and observation leading to development of California mastitis test. J. Am. Vet. Med. Assoc. 139:199-204.

Straub, J. A., C. Hertel, and W. P. Hammes. 1999. A 23S RNArtargeted polymerase chain reaction-based system for detection of Staphylococcus aureus in meat started cultures and dairy products. J. Food Prot. 62:1150-1156.

Taponen, S., H. Simojoki, M. Haveri, H. D. Larsen, and S. Pyörälä. 2006. Clinical characteristics and persistence of bovine mastitis caused by different species of coagulase-negative staphylococci identified with API or AFLP. Vet. Microbiol. 115:199-207.

Veras, J. F., D. A. Santos, and L. S. Carmo. 2003. Levantamento de surtos de toxinfecção alimentar envolvendo leite e produtos derivados no estado de Minas Gerais, Brasil. Higiene Alimentar $17: 218-222$.

Vuong, C., and M. Otto. 2002. Staphylococcus epidermidis infections. Microbes Infect. 4:481-489. 